Biol. Stud. 2021; 15(3): 29-40 • DOI: https://doi.org/10.30970/sbi.1503.662

www.http://publications.Inu.edu.ua/journals/index.php/biology

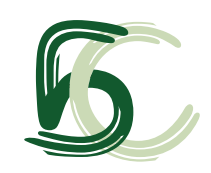

UDC: $57.084+57.6+58.085+604.6: 635.21$

\title{
APPLICATION OF POLYMERIC DIMETHYLAMINOETHYL METHACRYLATE-BASED CARRIERS OF PLASMID DNA FOR GENETIC TRANSFORMATION OF CERATODON PURPUREUS MOSS
}

\author{
N. S. Finiuk ${ }^{1,2}$, N. E. Mitina $\bigotimes^{3}$, \\ O. V. Lobachevska ${ }^{4}$, A. S. Zaichenko ${ }^{3}$, R. S. Stoika $0_{1,2}^{12}$ \\ ${ }_{1}^{1}$ Ivan Franko National University of Lviv, 4 Hrushevskyi St., Lviv 79005, Ukraine \\ 2 Institute of Cell Biology, NAS of Ukraine, 14-16 Drahomanov St., Lviv 79005, Ukraine \\ ${ }^{3}$ Lviv Polytechnic National University, 12 Bandera St., Lviv 79013, Ukraine \\ ${ }^{4}$ Institute of Ecology of the Carpathians, NAS of Ukraine, 4 Kozelnytska St., Lviv 79026, Ukraine \\ Finiuk, N.S., Mitina, N.E., Lobachevska, O.V., Zaichenko, A.S., \& Stoika, R.S. (2021). Application \\ of polymeric dimethylaminoethyl methacrylate based carriers of plasmid DNA for genetic \\ transformation of Ceratodon purpureus moss. Studia Biologica, 15(3): 29-40 • DOI: https://doi. \\ org/10.30970/sbi.1503.662
}

Introduction. Genetic engineering in plants is of great importance for agriculture, biotechnology and medicine, and nanomaterials are widely used for genetic engineering. The aim of the present study was to evaluate the potential of poly(2-dimethylamino) ethyl methacrylate (DMAEMA)-based comb-like polymers as gene delivery systems in moss Ceratodon purpureus (Hedw.) Brid. protoplasts and determine the level of phytotoxicity of these polymers.

Materials and Methods. In order to confirm the formation of a complex of polyDMAEMA carrier with plasmid DNA pSF3, gel retardation assay was used. The PEGmediated transformation protocol was adapted to transform the protoplasts of $C$. purpureus moss with poly-DMAEMA carriers. Light microscopy was used to study the toxicity of polymers for moss protoplasts. The level of the polymers toxicity was estimated as $\mathrm{IC}_{50}$ value.

Results and Discussion. The formation of pDNA complex with DMAEMA-based carriers took place at $0.03 \%$ concentration of the polymers BGA-21, BGA-22(2ph), BG-24, BG-25, BG-26 or $0.1 \%$ concentration of the BGA-22 polymer. Poly-DMAEMA carriers were able to deliver plasmid DNA pSF3 into protoplasts of $C$. purpureus moss. Three stable transformants of $C$. purpureus were obtained using BGA-22 polymer, 2 clones - using BGA-21 carrier, and 1 clone - using BGA-22(2ph), BG-24, BG-25,

() 2021 N. S. Finiuk et al. Published by the Ivan Franko National University of Lviv on behalf of Біологічні Студії / Studia Biologica. This is an Open Access article distributed under the terms of the Creative Commons Attribution 4.0 License which permits unrestricted reuse, distribution, and reproduction in any medium, provided the original work is properly cited.

ISSN 1996-4536 (print) • ISSN 2311-0783 (on-line) • Біологічні Студії / Studia Biologica • 2021 • Том 15 / № 3 • С. 29-40 
BG-26 polymers. Poly-DMAEMA carriers at the working dose of $0.0025 \%$ were relatively non-toxic for protoplasts of C. purpureus moss. $83.1-88.4 \%$ of viable protoplasts of C. purpureus moss were detected after treatment with studied carriers at a $0.0025 \%$ dose. A survival ratio of protoplasts reached $66.7-72.9 \%$ under the effect of these polymers at a $0.025 \%$ dose, which is 10 times higher than their working concentration. The $\mathrm{IC}_{50}$ value of poly-DMAEMA carriers was in the range of $0.113-0.164 \%$, which was approximately 10 times higher than that of the PEG-6000 used for gene delivery in plants.

Conclusion. Novel synthetic poly-DMAEMA carriers delivered the gene of interest into moss $C$. purpureus protoplasts and possessed a low level of phytotoxicity. Thus, these carriers can be useful for gene delivery into plant cells.

Keywords: dimethylaminoethyl-methacrylate, polymeric carrier, protoplasts transformation, moss Ceratodon purpureus, phytotoxicity

\section{INTRODUCTION}

Genetic engineering of plants is of great significance for agriculture, biotechnology and medicine. Agrobacterium-mediated and biolistic gene delivery methods are widely used tools for genetic transformation of plants. However, the efficiency of transformation remains a challenge because of the limitation of DNA transportation through the plant cell wall, damage of cells/tissues and a disruption of the transported gene [5].

Thus, the development of safe and efficient gene carriers becomes one of the prerequisites for the successful targeted gene transfer. Nanocomposites are widely used in biotechnology and medicine, namely for DNA transfer into the target cells. Cationic polymers have been developed for various biotechnological and biomedical applications. As drug carrier systems, they are widely used for delivery of proteins and peptides, as well as nonviral DNA and RNA vectors [16, 28]. Recently, such polycationic carries as poly(L-lysine) (PLL), poly(amidoamine) (PAMAM), poly(ethylenimine) (PEI), polymethacrylates (e.g. poly(2-dimethylamino)ethyl methacrylate (DMAEMA)) have been developed for gene delivery $[2,16,20]$. Poly-DMAEMA-based polymers were found to be efficient gene transfer carriers into mammalian [1, 6, 19, 22], yeast [7], and plant [8, 9] cells.

The toxic action of polymeric carriers could be a problem in gene therapy and biotechnology $[1,2,12,13,26]$. The evaluation of toxicity of polymeric carriers is an important step towards assessing the potential risks of their application. Low cytotoxicity of DMAEMA-based polymers toward mammalian cells was reported $[2,17,18,23]$. However, the literature does not contain enough information about the phytotoxicity and mutagenicity of DMAEMA-based polymers $[8,10]$.

The present study was focused on studying the potential of DMAEMA-based block polymers as gene delivery systems for moss Ceratodon purpureus protoplasts and determining their biocompatibility.

\section{MATERIALS AND METHODS}

DMAEMA-based block polymers. Materials used for synthesis of the polymers: 2-(dimethylamino)ethyl methacrylate (DMAEMA), 2-aminoethyl methacrylate hydrochloride (AEM), vinyl acetate (VA), maleic anhydride (MA), poly(ethylene glycol) methyl ether methacrylate (Mn 470 and $1000 \mathrm{~g} \mathrm{~mol}^{-1}$ (Da)) (PEEM470 and PEEM1000), isopropylbenzene (IPB) were from Aldrich (Milwaukee, WI, USA). N,N-Dimethylformamide (DMF), 1.4-dioxane, acetone and n-hexane obtained from Merck (Darmstadt, Germany).

ISSN 1996-4536 (print) • ISSN 2311-0783 (on-line) • Біологічні Студії / Studia Biologica • 2021 • Том 15 / № 3 • С. 29-40 
Synthesis of polymers: Novel DMAEMA-containing comb-like polymers were synthesized at the Department of Organic Chemistry of Lviv Polytechnic National University (Lviv, Ukraine) in two stages as described previously [28]: 1) the synthesis of polyfunctional macroinitiators (oligoperoxide metal complex (OMC) with side peroxide groups or telechelic oligoperoxides - polyalcyl acrylate with terminal peroxide groups), and 2) the synthesis by grafting radical polymerization of polycationic polymer chains. The structures and compositions of polymers are shown in Fig. 1, and Table 1.
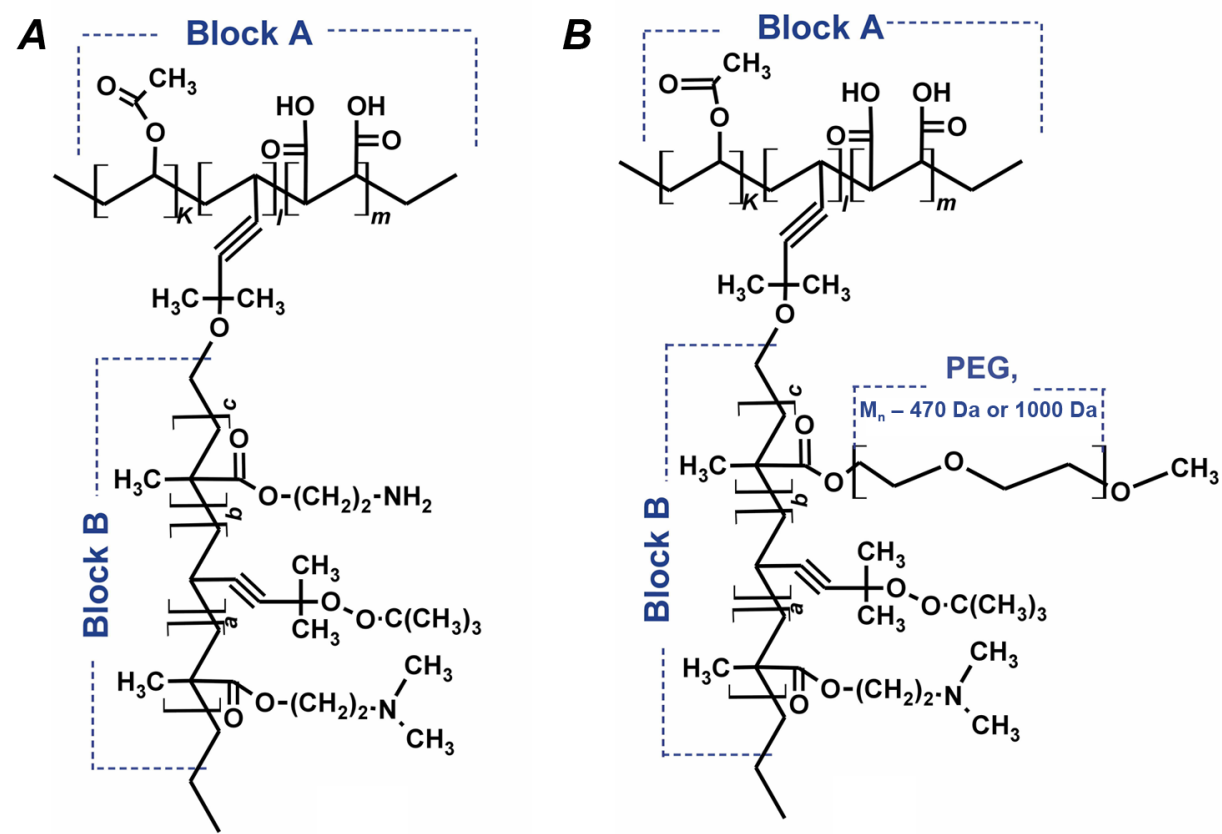

Fig. 1 Schematic structure of the polymeric carriers: $\boldsymbol{A}$ - BGA-21, BGA-22, BGA-22(2ph); $\boldsymbol{B}-$ BG-24, BG-25, BG-26

Рис. 1. Схематична структура полімерних носіїв: $\boldsymbol{A}$ - BGA-21, BGA-22, BGA-22(2ph); $\boldsymbol{B}$ - BG-24, BG-25, BG-26

Table 1. Comb-like polymers composition and molecular-mass characteristics Таблиця 1. Склад гребінчастих полімерів, їхні молекулярно-масові характеристики

\begin{tabular}{|c|c|c|c|c|c|c|c|}
\hline \multirow{3}{*}{ Polymers } & \multirow{3}{*}{$\begin{array}{c}\text { Backbone }- \text { Block } A \\
(O M C \text { with } \\
\left.M_{n}=2.0 \mathrm{kDa}\right) \\
\% \mathrm{~mol}\end{array}$} & \multicolumn{5}{|c|}{ Grafted chain - Block B } & \multirow{3}{*}{$M_{n}, k D a$} \\
\hline & & \multicolumn{5}{|c|}{ Composition, \% mol } & \\
\hline & & DMAEMA & VEP & AEM & PEEM470 & PEEM 1000 & \\
\hline BGA21 & 1.2 & 85.3 & 7.5 & 6.0 & - & - & 8.4 \\
\hline BGA22 & 1.2 & 86.3 & 8.7 & 3.8 & - & - & 8.9 \\
\hline BG24 & 1.2 & 90.4 & 7.7 & - & 0.7 & - & 16.5 \\
\hline BG25 & 1.2 & 92.7 & 4.3 & - & 1.8 & - & 17.9 \\
\hline BG26 & 0.9 & 90.4 & 8.3 & - & - & 0.4 & 26.1 \\
\hline
\end{tabular}

To obtain mixed micelles (sample BGA-22(2ph)), $0.5 \mathrm{~mL}$ of $20 \%$ solution of L- $\alpha$ phosphatidylcholine (Ph) (Sigma-Aldrich, USA) in chloroform (Sigma-Aldrich, USA) was added to $5 \mathrm{~mL}$ of the solution of BGA-22 (1 mg/mL, $\mathrm{pH} 7.2)$ and sonicated for $25 \mathrm{~s}$.

ISSN 1996-4536 (print) • ISSN 2311-0783 (on-line) • Біологічні Студії / Studia Biologica • 2021 • Том 15 / № 3 • С. 29-40 
Then, chloroform was evaporated at $60{ }^{\circ} \mathrm{C}$ and stirred for $2 \mathrm{~h}$, and the sample was vacuumized for $1 \mathrm{~h}$.

Formation of polymer/pDNA complex. The polymer/pDNA complexes were prepared as described previously [8] by adding the polymer $(1 \mu \mathrm{L})$ at increasing concentrations $(0.003-0.1 \%)$ to the plasmid DNA $(1 \mu \mathrm{g})$ pEGFPc-1 (Clontech, USA) on $6 \mu \mathrm{L}$ of $20 \mathrm{mM}$ Tris- $\mathrm{HCl}, \mathrm{pH}$ 7.4. The complexes were incubated for $20 \mathrm{~min}$ at room temperature. Then, the polymer/pDNA complexes were loaded onto $1 \%$ agarose gel (Lachema, Czech Republic) and run with 1x Tris-acetate buffer containing $1 \mu \mathrm{g} / \mathrm{mL}$ of Ethydium Bromide (Sigma-Aldrich, USA). Electrophoresis was performed for approximately $1 \mathrm{~h}$ at a constant voltage of $90 \mathrm{~V}$. Plasmid DNA bands were visualized with an UV transilluminator (MacroVue UV-20, Hoeffer, USA).

Transformation of moss protoplasts. Moss Ceratodon purpureus (the Collection of the Institute of Ecology of the Carpathians, National Academy of Sciences of Ukraine, Lviv, Ukraine) was cultured at $24-26{ }^{\circ} \mathrm{C}$ in a solid Knop medium [4] with light intensity of $5-20 \mathrm{~W} / \mathrm{m}^{2}$ with an alternate $16 / 8 \mathrm{~h}$ day/night cycle. The culture of $C$. purpureus was initiated from the spores. Protoplasts of $C$. purpureus were isolated by digestion of cell walls of $100 \mathrm{mg}$ of protonemal tissue with $1 \%$ Driselase (Sigma-Aldrich, USA) for $1 \mathrm{~h}$ in darkness at room temperature with slight continuous shaking. The digested moss tissue was transferred to the wet with a D-mannitol (Sigma-Aldrich, USA) nylon filter. The tube with the filtrated protoplasts was centrifuged at $200 \times \mathrm{g}$ for $5 \mathrm{~min}$. The pellet was gently resuspended in $10 \mathrm{~mL}$ of $9 \%$ D-mannitol. The number of protoplasts was counted using Neubauer chamber [15]. Protoplasts were recentrifuged at $200 \times \mathrm{g}$ for $5 \mathrm{~min}$. The pellet was gently resuspended in the MMM solution (9\% D-mannitol, $0.015 \mathrm{M} \mathrm{MgCl}_{2}, 0.1 \% \mathrm{MES}-\mathrm{KOH}$, $\mathrm{pH}$ 5.6) to obtain the protoplasts suspension at the concentration of $1.6 \times 10^{6} / \mathrm{mL}$ [4].

Plasmid DNA pSF3 $[8,9]$ that contained a gene of green fluorescent protein and hygromycin B resistance gene was used to transform the protoplasts of $C$. purpureus moss. The modified method of PEG-mediated transformation, developed for moss Physcomitrella patens, was used to transform the protoplasts of $C$. purpureus $[4,11]$. The pDNA complexes with the poly-DMAEMA carrier ( $1 \mu \mathrm{L}$ of pDNA and $2.5 \mu \mathrm{L}$ of $0.1 \%$ of polymer) or with $2.5 \mu \mathrm{L}$ of $40 \%$ PEG-6000 (LobaChemie, Austria) were used for moss protoplasts transformation. Complexes were added to $0.1 \mathrm{~mL}$ of protoplasts in the MMM solution (the final concentration of polymeric carriers was $0.0025 \%$ ). Tubes with transformed protoplasts were transfered in a light-tight cardboard box and incubated for $24 \mathrm{~h}$ at $24-26{ }^{\circ} \mathrm{C}$. The transformed protoplasts were mixed with $2 \mathrm{~mL}$ of PRMT medium (approximately $37-42^{\circ} \mathrm{C}$ ) and placed on Petri dishes $(9 \mathrm{sm}$ ) with a solid PRMB medium containing $0.5 \%$ glucose. The regenerants were transferred on a selective medium containing hygromycin B (50 $\mu \mathrm{g} / \mathrm{mL}$, Sigma-Aldrich, USA) after 14 days at $24-26{ }^{\circ} \mathrm{C}$ with light intensity of $5-20 \mathrm{~W} / \mathrm{m}^{2}$ with alternate $16 / 8 \mathrm{~h}$ day/night cycle. The regenerants were sub-cultivated for next 14 days on the medium without or with hygromycin $B$ antibiotic for approximately 8 weeks in order to obtain stable transformants [8].

Toxicity of polymers for moss protoplasts. The effects of poly-DMAEMA carriers and PEG-6000 on C. purpureus protoplasts were studied in the following range of the final carriers' concentrations of 0.0025 (working concentration), 0.025 and $0.25 \%$. Polymers were added to $0.1 \mathrm{~mL}$ aliquots of protoplasts suspension $\left(1.6 \times 10^{6} / \mathrm{mL}\right)$ in $8 \%$ of D-mannitol and gently mixed by pipetting. Protoplasts were co-cultivated with the carriers for $24 \mathrm{~h}$ at $24-26^{\circ} \mathrm{C}$ with light intensity of $5-20 \mathrm{~W} / \mathrm{m}^{2}$ with an alternate $16 / 8 \mathrm{~h}$ day/ night cycle. The cytotoxicity of polymers was examined by calculating the amount of normal and damaged protoplasts using Neubauer chamber [15]. The level of polymer

ISSN 1996-4536 (print) • ISSN 2311-0783 (on-line) • Біологічні Студії / Studia Biologica • 2021 • Том 15 / № 3 • С. 29-40 
toxicity was evaluated using $\mathrm{IC}_{50}$ value (concentration of polymer that reduced protoplasts viability by $50 \%$ ).

Data analysis. All data are presented as a Mean (M) \pm Standard deviation (SD) from three replications. Statistical analysis was performed using one-way ANOVA test at GraphPad Prism 6 software (RRID:SCR_002798). P value of < 0.05 was considered as statistically significant.

\section{RESULTS AND DISCUSSION}

pDNA binding properties of polymers. The electrostatic interactions between positively charged groups of the carrier and negatively charged phosphate groups of DNA are important for DNA binding and efficient delivery [24].

A gel retardation assay was used to confirm the formation of poly-DMAEMA carrier and plasmid DNA pEGFPc-1 complex. Plasmid DNA migrated during agarose gel electrophoresis (lane 5 of Fig. 2). The electrophoretic mobility of pDNA slowed down with an increase of the polymer concentration. The retardation of pDNA migration was found when it was mixed with $0.03 \%$ of BGA-21 (lane 2 of Fig. $2 A$ ) point to the polymer/pDNA complex formation. The formation of a pDNA complex with BGA-22(2ph), BG-24, BG-25, BG-26 took place at $0.03 \%$ concentration of the polymer (Fig. 2C-F). BGA-22 at $0.01 \%$ form complex with pDNA (lane 3 of Fig. 2B).
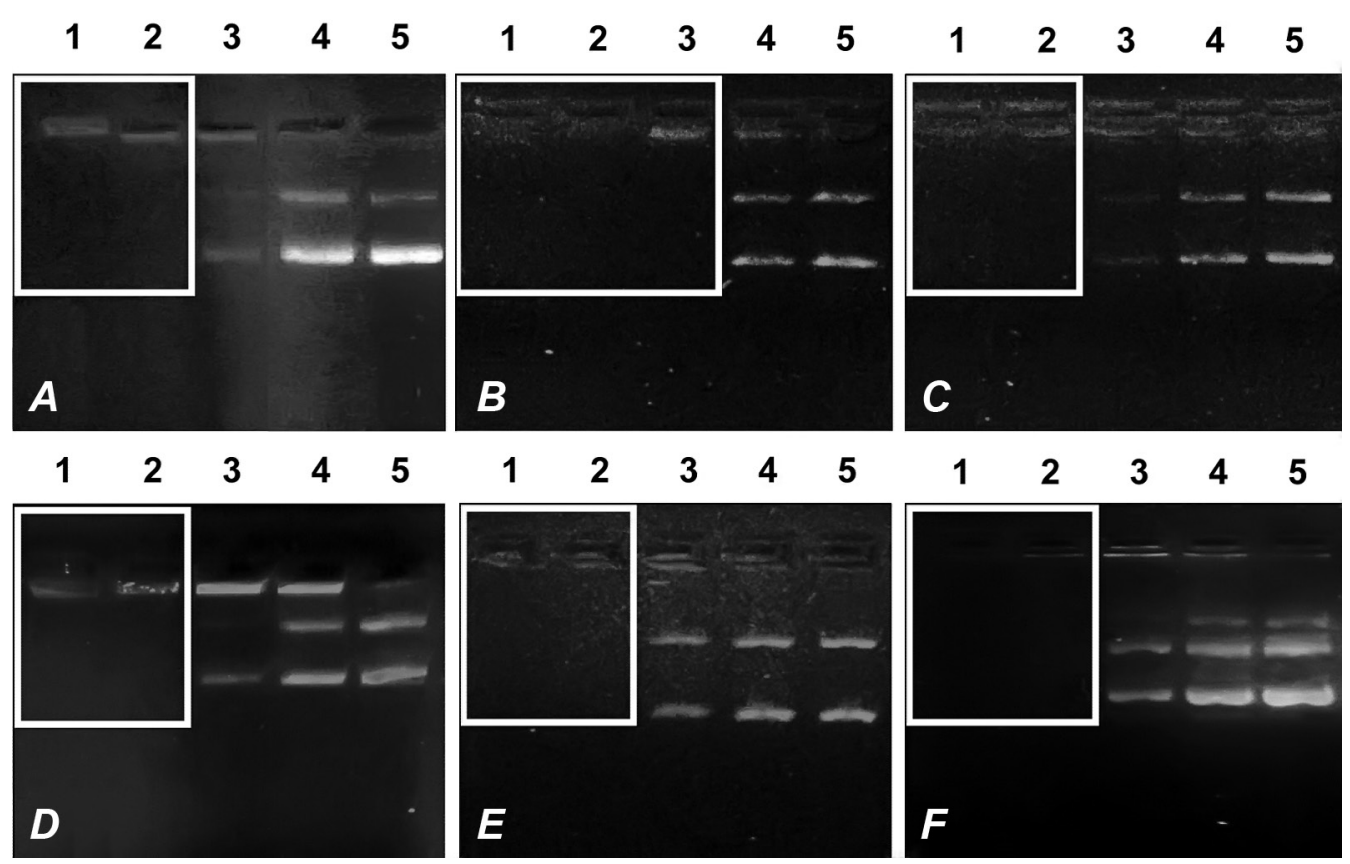

Fig. 2. Electrophoregram of gel retardation assay of the polymeric carriers BGA-21 $(\boldsymbol{A}), B G A-22(\boldsymbol{B}), B G A-$ 22(2ph) (C), BG-24 (D), BG-25 (E), BG-26 $(\boldsymbol{F})$ and plasmid pEGFPc-1 complexes in 1\% agarose gel. Lines $1-$ pDNA $+0.1 \%$ of polymer; 2 - pDNA $+0.03 \%$ of polymer; $3-p D N A+0.01 \%$ of polymer; $4-$ pDNA $+0.003 \%$ of polymer; $\mathbf{5}$ - intact pDNA. The white rectangle points to the polymer/pDNA complex

Рис. 2. Електрофореграма ДНК плазміди pEGFPc-1 і полімерних носіїв BGA-21 (A), BGA-22 (B), BGA-22(2ph) (C), BG-24 (D), BG-25 $(\boldsymbol{E})$, BG-26 $(\boldsymbol{F})$ в 1\% гелі агарози. Лінія $1-$ пДНК $+0,1 \%$ полімер; 2 - пДНК + 0,03\% полімер; 3 - пДНК + 0,01\% полімер; 4 - пДНК + 0,003\% полімер; 5 інтактна пДНК. Білий прямокутник вказує на комплекс полімер/пДНК

ISSN 1996-4536 (print) • ISSN 2311-0783 (on-line) • Біологічні Студії / Studia Biologica • 2021 • Том 15 / № 3 • С. 29-40 
All studied poly-DMAEMA carriers at concentration of $0.03-0.1 \%$ were able to form complexes with plasmid DNA.

Transformation of Ceratodon purpureus moss. We adapted the protocol of PEGmediated transformation of moss protoplasts to transform the C. purpureus moss protoplasts using poly-DMAEMA carriers. We were not able to obtain moss transformants by application of the conventional PEG-based transformation method [4] (Fig. 3G). Three stable transformants of $C$. purpureus were obtained using BGA-22 polymer, 2 clones when using BGA-21 carrier, and 1 clone - when using BGA-22(2ph), BG-24, BG-25, BG-26 polymers (Fig. 3, Table 2).
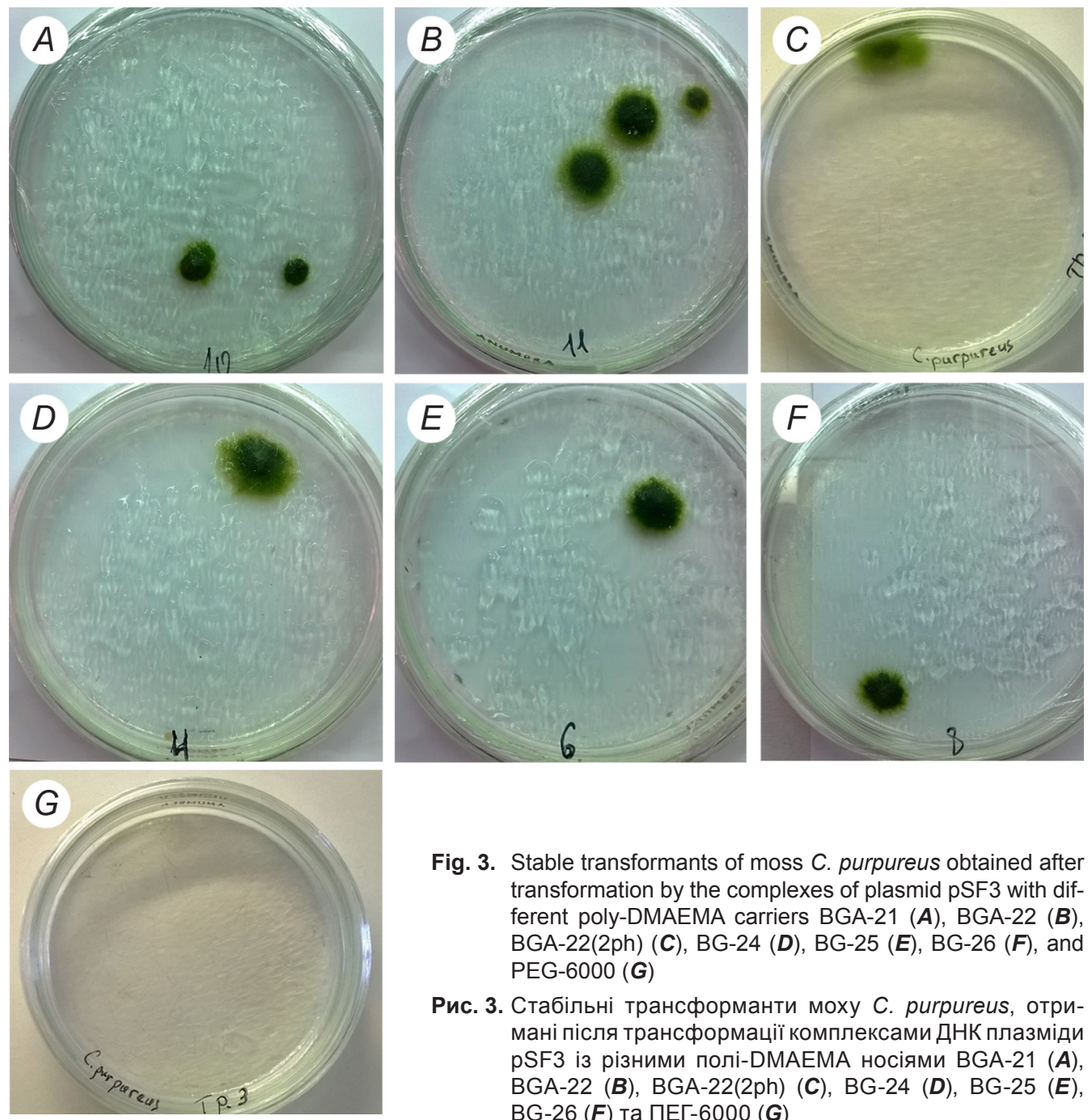

Fig. 3. Stable transformants of moss C. purpureus obtained after transformation by the complexes of plasmid pSF3 with different poly-DMAEMA carriers BGA-21 $(\boldsymbol{A}), \mathrm{BGA}-22(\boldsymbol{B})$, BGA-22(2ph) $(\boldsymbol{C})$, BG-24 $(\boldsymbol{D})$, BG-25 $(\boldsymbol{E})$, BG-26 $(\boldsymbol{F})$, and PEG-6000 (G)

Рис. 3. Стабільні трансформанти моху C. purpureus, отримані після трансформації комплексами ДНК плазміди pSF3 із різними полі-DMAEMA носіями BGA-21 $(\boldsymbol{A})$, BGA-22 (B), BGA-22(2ph) (C), BG-24 (D), BG-25 (E), BG-26 $(\boldsymbol{F})$ та ПЕГ-6000 (G)

Thus, poly-DMAEMA carriers BGA-21, BGA-22, BGA-22(2ph), BG-24, BG-25, and BG-26 were able to deliver plasmid DNA pSF3 into protoplasts of $C$. purpureus.

ISSN 1996-4536 (print) • ISSN 2311-0783 (on-line) • Біологічні Студії / Studia Biologica • 2021 • Том 15 / № 3 • С. 29-40 
Table 2. The effectiveness of the transformation of $C$. purpureus moss protoplasts using poly-DMAEMA and PEG-6000 as PDNA carriers

Таблиця 2. Ефективність трансформації протопластів моху C. purpureus із використанням полі-ДМАЕМА і ПЕГ-6000 як носіїв пДНК

\begin{tabular}{c|c}
\hline Polymer & The number of transformants \\
\hline BGA-22 & 3 \\
BGA-21 & 2 \\
BGA-22(2ph) & 1 \\
BGA-24 & 1 \\
BGA-25 & 1 \\
BGA-26 & 1 \\
PEG-6000 & 0 \\
\hline
\end{tabular}

Toxicity of polymers towards protoplasts of C. purpureus. All poly-DMAEMA carriers demonstrated a slight decrease in the level of viability of $C$. purpureus protoplasts (Fig. 4).

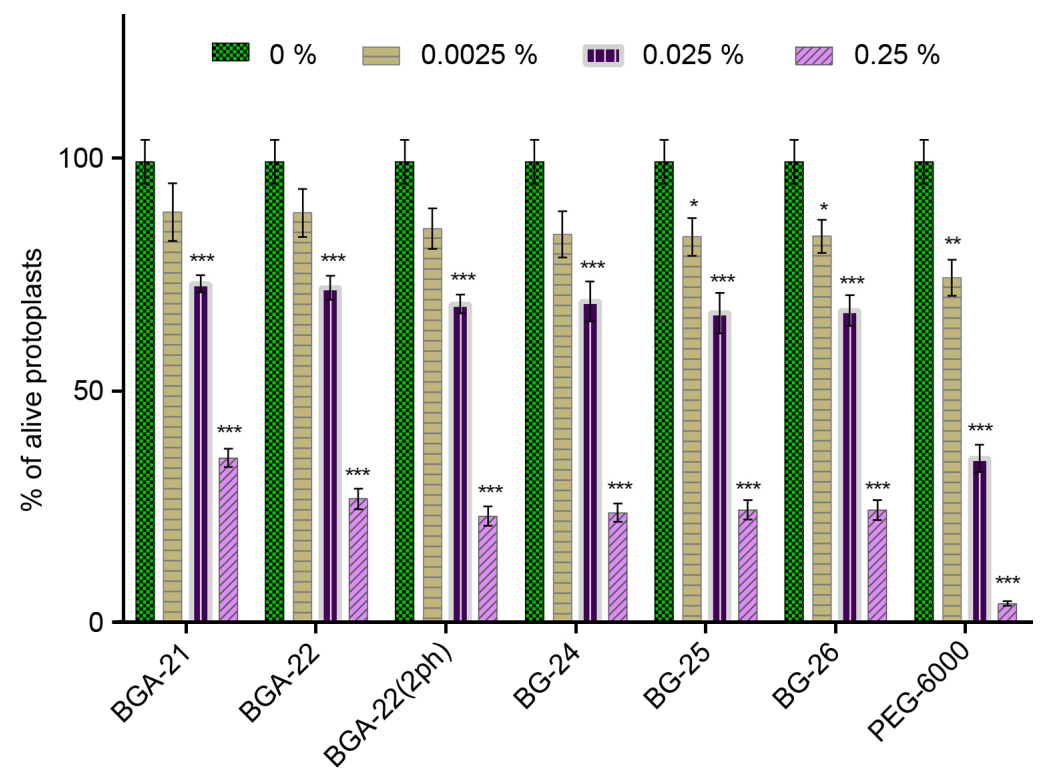

Fig. 4. The effect of poly-DMAEMA carriers and PEG-6000 at different concentrations on viability of C. purpureus protoplasts

Рис. 4. Вплив полі-ДМАЕМА носіїв і ПЕГ-6000 у різних концентраціях на життєздатність протопластів C. purpureus

The levels of viable protoplasts after treatment with BGA-21, BGA-22 and BGA22(2ph), BG-24, BG-25 and BG-26 at the concentration of $0.0025 \%$, that was used for transformation of $C$. purpureus protoplasts, was of $88.4,88.2,84.8,83.5,83.1$ and $83.1 \%$, respectively (Fig. 4). A survival ratio of protoplasts reached $66.7-72.9 \%$ under the effect of these polymers at $0.025 \%$ (10 times higher than working concentration).

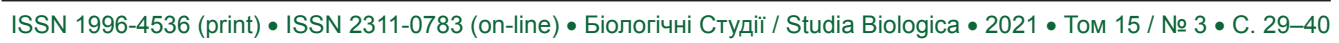


The polymers at $0.25 \%$ (100 times higher than working concentration) decreased the viability of protoplasts to $23.1-35.6 \%$. The most pronounced cytotoxic effects were found for PEG-6000. PEG-6000 used at $0.0025,0.025$ and $0.25 \%$ decreased moss C. purpureus protoplasts viability to $74.3,35.5$ and $4.3 \%$, respectively (Fig. 4). The $\mathrm{IC}_{50}$ value of BGA21 was 0.164\%; 0.135 - for BGA-22; 0.119 - for BG-24; 0.117 - for BG-26 and BGA-22(2ph); 0.113 - for BG-25. The IC ${ }_{50}$ value of PEG-6000 was $0.016 \%$.

Different studies reported that modification of polymers with PEGylation substantially reduce the toxicity of carriers against mammalian cells $[14,16,21,22,25]$. Here, we found that the efficiency of PEG-containing DMAEMA-based polymers as gene delivery vectors for transformation of moss protoplasts was relatively low. The transformation efficiency of PEG-containing poly-DMAEMA carriers was not associated with the increased cytotoxicity of these carries. Previously, we found that poly-DMAEMA carriers did not demonstrate a genotoxic action in the ana-telophase test in $A$. cepa, and in the Ames test (with and without metabolic activation) [10]. One can speculate that PEGcontaining poly-DMAEMA carriers form highly stable complexes with pDNA that reduced the dissociation of the polyplex. Previously, we demonstrated that linear DMAEMAbased polymers were more effective for plant transformation. 25 stable transformants of C. purpureus were obtained using TN $83 / 6$ and 26 stable transformants - using TN 84/5. At the same time, a PEG-containing carrier DLM-9-DM was considerably less effective in C. purpureus transformation [8].

\section{CONCLUSION}

The studied poly-DMAEMA carriers form complexes with plasmid DNA. PolyDMAEMA carriers are capable of delivering plasmid DNA pSF3 into protoplasts of C. purpureus moss. The poly-DMAEMA carriers at working concentration were relatively non-toxic for protoplasts of $C$. purpureus moss. The poly-DMAEMA carriers at $0.113-0.164 \%$ (approximately 45 times higher concentration than that used for moss transformation) reached their $\mathrm{IC}_{50}$ value. Thus, novel synthetic poly-DMAEMA carriers demonstrate their prospects as a system for the delivery of plasmid DNA into plant cells.

\section{ACKNOWLEDGMENTS}

This work was partly supported by the Research Grants from the National Academy of Sciences of Ukraine (0115U004198 and 0120U100197).

\section{COMPLIANCE WITH ETHICAL STANDARDS}

Conflict of Interests: The authors declare that the research was conducted in the absence of any commercial or financial relationships that could be construed as a potential conflict of interest.

Human Rights: This article does not contain any studies with human subjects performed by any of the authors.

Animal Studies: This article does not contain any studies with animal subjects performed by the any of the authors.

\section{AUTHOR CONTRIBUTIONS}

Conceptualization, [RSS, ASZ, NSF]; methodology, [RSS, ASZ, OVL, NSF, NEM]; polymers synthesis and characterization, [NEM, ASZ]; moss culture, [OVL, NSF]; DNA

ISSN 1996-4536 (print) • ISSN 2311-0783 (on-line) • Біологічні Студії / Studia Biologica • 2021 • Том 15 / № 3 • С. 29-40 
electrophoresis, moss transformation, toxicity study, [NSF]; data analysis, [NSF, OVL, NEM, ASZ, RSS]; writing - original draft preparation, [NSF]; writing - review and editing, [RSS, NSF, OVL, NEM, ASZ]; visualization, [NSF]; supervision, [RSS, ASZ]; funding acquisition, [RSS, NSF].

1. Arnold, A.E., Czupiel, P., \& Shoichet, M. (2017). Engineered polymeric nanoparticles to guide the cellular internalization and trafficking of small interfering ribonucleic acids. Journal of Controlled Release, 259, 3-15.

Crossref $\bullet$ PubMed $\bullet$ Google Scholar

2. Cerda-Cristerna, B.I., Flores, H., Pozos-Guillén, A., Pérez, E., Sevrin, C., \& Grandfils, C. (2011). Hemocompatibility assessment of poly(2-dimethylamino ethylmethacrylate) (PDMAEMA)based polymers. Journal of Controlled Release, 153(3), 269-277.

Crossref $\bullet$ PubMed $\bullet$ Google Scholar

3. Cheng, Q., Du, L., Meng, L., Han, S., Wei, T., Wang, X., Wu, Y., Song, X., Zhou, J., Zheng, S., Huang, Y., Liang, X.J., Cao, H., Dong, A., \& Liang, Z. (2016). The promising nanocarrier for doxorubicin and siRNA co-delivery by PDMAEMA-based amphiphilic nanomicelles. ACS Applied Materials \& Interfaces, 8(7), 4347-4356.

Crossref $\bullet$ PubMed $\bullet$ Google Scholar

4. Cove, D.J., Perroud, P.F., Charron, A.J., McDaniel, S.F., Khandelwal, A., \& Quatrano, R.S. (2009). The moss Physcomitrella patens: a novel model system for plant development and genomic studies. Cold Spring Harbor protocols, 2009(2), pdb.emo115-pdb.emo115.

Crossref $\bullet$ PubMed $\bullet$ Google Scholar

5. Cunningham, F.J., Goh, N.S., Demirer, G.S., Matos, J.L., \& Landry, M.P. (2018). Nanoparticlemediated delivery towards advancing plant genetic engineering. Trends in Biotechnology, 36(9), 882-897.

Crossref $\bullet$ PubMed $\bullet$ Google Scholar

6. Ficen, S.Z., Guler, Z., Mitina, N., Finiuk, N., Stoika, R., Zaichenko, A., \& Ceylan S.E. (2013). Biophysical study of novel oligoelectrolyte based non-viral gene delivery systems to mammalian cells. The Journal of Gene Medicine, 15(5), 193-204.

Crossref $\bullet$ PubMed $\bullet$ Google Scholar

7. Filyak, Y., Finiuk, N., Mitina, N., Bilyk, O., Titorenko, V., Hrydzhuk, O., Zaichenko, A., \& Stoika, R. (2013). A novel method for genetic transformation of yeast cells using oligoelectrolyte polymeric nanoscale carriers. BioTechniques, 54(1), 35-43.

Crossref $\bullet$ PubMed $\bullet$ Google Scholar

8. Finiuk N., Buziashvili, A., Burlaka, O., Zaichenko, A., Mitina, N., Miagkota, O., Lobachevska, O., Stoika, R., Blume, Ya., \& Yemets, A. (2017). Investigation of novel oligoelectrolyte polymer carriers for their capacity of DNA delivery into plant cells. Plant Cell, Tissue and Organ Culture (PCTOC), 131(1), 27-39.

Crossref $\bullet$ Google Scholar

9. Finiuk, N., Chaplya, A., Mitina, N., Boiko, N., Lobachevska, O., Miahkota, O., Yemets, A.I., Blume, Ya.B., Zaichenko, O.S., \& Stoika, R.S. (2014). Genetic transformation of moss Ceratodon purpureus by means of polycationic carriers of DNA. Cytology and Genetics, 48(6), 345-351.

Crossref $\bullet$ Google Scholar

10. Finiuk, N., Romanyuk, N., Mitina, N., Lobachevska, O., Zaichenko, A., Terek, O., \& Stoika, R. (2020). Evaluation of phytotoxicity and mutagenicity of novel DMAEMA-containing gene carriers. Cytology and Genetics, 54(5), 437-448.

Crossref $\bullet$ Google Scholar

11. Frank, W., Decker, E. L., \& Reski, R. (2005). Molecular tools to study Physcomitrella patens. Plant Biology, 7(3), 220-227.

Crossref $\bullet$ PubMed $\bullet$ Google Scholar

ISSN 1996-4536 (print) • ISSN 2311-0783 (on-line) • Біологічні Студії / Studia Biologica • 2021 • Том 15 / № 3 • С. 29-40 
12. Funhoff, A.M., van Nostrum, C.F., Lok, M.C., Kruijtzer, J.A., Crommelin, D.J., \& Hennink, W.E. (2005). Cationic polymethacrylates with covalently linked membrane destabilizing peptides as gene delivery vectors. Journal of Controlled Release, 101(1-3), 233-246.

Crossref $\bullet$ PubMed • Google Scholar

13. Idrees, H., Zaidi, S., Sabir, A., Khan, R.U., Zhang, X., \& Hassan, S.U. (2020). A review of biodegradable natural polymer-based nanoparticles for drug delivery applications. Nanomaterials, 10(10), 1970.

Crossref $\bullet$ PubMed $\bullet$ PMC $\bullet$ Google Scholar

14. Lin, S., Du, F., Wang, Y., Ji, S., Liang, D., Yu, L., \& Li, Z. (2008). An acid-labile block copolymer of PDMAEMA and PEG as potential carrier for intelligent gene delivery systems. Biomacromolecules, 9(1), 109-115.

Crossref $\bullet$ PubMed $\bullet$ Google Scholar

15. Liu, Y., \& Vidali, L. (2011). Efficient polyethylene glycol (PEG) mediated transformation of the moss Physcomitrella patens. Journal of Visualized Experiments, 50, e2560.

Crossref $\bullet$ PubMed $\bullet$ PMC $\bullet$ Google Scholar

16. Lv, H., Zhang, S., Wang, B., Cui, S., \& Yan, J. (2006). Toxicity of cationic lipids and cationic polymers in gene delivery. Journal of Controlled Release, 114(1), 100-109.

Crossref $\bullet$ PubMed $\bullet$ Google Scholar

17. Mendrek, B., Fus, A., Klarzyńska, K., Sieroń, A. L., Smet, M., Kowalczuk, A., \& Dworak, A. (2018). Synthesis, characterization and cytotoxicity of novel thermoresponsive star copolymers of $N, N^{\prime}$-dimethylaminoethyl methacrylate and hydroxyl-bearing oligo(ethylene glycol) methacrylate. Polymers, 10(11), 1255.

Crossref $\bullet$ PubMed $\bullet$ PMC $\bullet$ Google Scholar

18. Newland, B., Abu-Rub, M., Naughton, M., Zheng, Y., Pinoncely, A. V., Collin, E., Dowd, E., Wang, W., \& Pandit, A. (2013). GDNF gene delivery via a 2-(dimethylamino)ethyl methacrylate based cyclized knot polymer for neuronal cell applications. ACS Chemical Neuroscience, 4(4), 540-546.

Crossref $\bullet$ PubMed $\bullet$ PMC $\bullet$ Google Scholar

19. Paiuk, O., Mitina, N., Slouf, M., Pavlova, E., Finiuk, N., Kinash, N., Karkhut, A., Manko, N., Gromovoy, T., Hevus, O., Shermolovich, Y., Stoika, R., \& Zaichenko, A. (2019). Fluorinecontaining block/branched polyamphiphiles forming bioinspired complexes with biopolymers. Colloids and Surfaces B: Biointerfaces, 174, 393-400.

Crossref $\bullet$ PubMed $\bullet$ Google Scholar

20. Plamper, F.A., Synatschke, C.V., Majewski, A.P., Schmalz, A., Schmalz, H., \& Müller, A.H.E. (2014). Star-shaped poly[2-(dimethylamino)ethyl methacrylate]and its derivatives: toward new propertiesand applications. Polimery, 59, 66-73.

Crossref $\bullet$ Google Scholar

21. Qian, Y., Zha, Y., Feng, B., Pang, Z., Zhang, B., Sun, X., Ren, J., Zhang, C., Shao, X., Zhang, Q., \& Jiang, X. (2013). PEGylated poly(2-(dimethylamino) ethyl methacrylate)/DNA polyplex micelles decorated with phage-displayed TGN peptide for brain-targeted gene delivery. Biomaterials, 34(8), 2117-2129.

Crossref $\bullet$ PubMed $\bullet$ Google Scholar

22. Qiao, Y., Huang, Y., Qiu, C., Yue, X., Deng, L., Wan, Y., Xing, J., Zhang, C., Yuan, S., Dong, A., $\& \mathrm{Xu}, \mathrm{J}$. (2010). The use of PEGylated poly [2-(N,N-dimethylamino) ethyl methacrylate] as a mucosal DNA delivery vector and the activation of innate immunity and improvement of HIV-1-specific immune responses. Biomaterials, 31(1), 115-123.

Crossref $\bullet$ PubMed $\bullet$ Google Scholar

23. Robbens, J., Vanparys, C., Nobels, I., Blust, R., Van Hoecke, K., Janssen, C., De Schamphelaere, K., Roland, K., Blanchard, G., Silvestre, F., Gillardin, V., Kestemont, P., Anthonissen, R., Toussaint, O., Vankoningsloo, S., Saout, C., Alfaro-Moreno, E., Hoet, P., Gonzalez, L., Dubruel, P., \& Troisfontaines, P. (2010). Eco-, geno- and human toxicology of bio-active nanoparticles for biomedical applications. Toxicology, 269(2-3), 170-181.

Crossref $\bullet$ PubMed $\bullet$ Google Scholar

ISSN 1996-4536 (print) • ISSN 2311-0783 (on-line) • Біологічні Студії / Studia Biologica • 2021 • Том 15 / № 3 • С. 29-40 
24. Shi, B., Zheng, M., Tao, W., Chung, R., Jin, D., Ghaffari, D., \& Farokhzad, O.C. (2017). Challenges in DNA delivery and recent advances in multifunctional polymeric DNA delivery systems. Biomacromolecules, 18(8), 2231-2246.

Crossref $\bullet$ PubMed $\bullet$ Google Scholar

25. Suk, J.S., Xu, Q., Kim, N., Hanes, J., \& Ensign, L.M. (2016). PEGylation as a strategy for improving nanoparticle-based drug and gene delivery. Advanced Drug Delivery Reviews, 99, 28-51.

Crossref $\bullet$ PubMed $\bullet$ PMC $\bullet$ Google Scholar

26. Thotakura, N., Parashar, P., \& Raza, K. (2021). Assessing the pharmacokinetics and toxicology of polymeric micelle conjugated therapeutics. Expert Opinion on Drug Metabolism \& Toxicology, 17(3), 323-332.

Crossref $\bullet$ PubMed $\bullet$ Google Scholar

27. Tomlinson, E., \& Rolland A.P. (1996). Controllable gene therapy: pharmaceutics of non-viral gene delivery systems. Journal of Controlled Release, 39, 357-72.

Crossref $\bullet$ Google Scholar

28. Zaichenko, A., Mitina, N., Shevchuk, O., Rayevska, K., Lobaz, V., Skorokhoda, T., \& Stoika, R. (2008). Development of novel linear, block and branched oligoelectrolytes and functionally targeting nanoparticles. Pure and Applied Chemistry, 80(11), 2309-2326.

Crossref • Google Scholar

\section{ВИКОРИСТАННЯ ПОЛІ(ДИМЕТИЛАМІНО) ЕТИЛМЕТАКРИЛАТ-ВМІСНИХ НОСІЇВ ДНК ПЛАЗМІДИ ДЛЯ ТРАНСФОРМАЦІЇ МОХУ CERATODON PURPUREUS}

Н. С. Фінюк ${ }^{1,2}$, Н. Є. Мітіна ${ }^{3}$, О. В. Лобачевська ${ }^{4}$, О. С. Заіченко ${ }^{3}$ Р. С. Стойка ${ }^{1,2}$

1 Львівський національний університет імені Івана Франка вул. Грушевського, 4, Львів 79005, Україна

2 Інститут біології клітини НАН України, вул. Драгоманова, 14/16, Львів 79005, Україна ${ }^{3}$ Національний університет “Львівська політехніка", вул. Бандери, 12, Львів 79013, Україна

${ }^{4}$ Інститут екології Карпат НАН України, вул. Козельницька, 4, Львів 79026, Україна

Обґрунтування. Генна інженерія рослин $€$ перспективною галуззю в сільському господарстві, біотехнології, медицині. На сьогодні наноматеріали є привабливими системами для генетичної інженерії рослин. Метою представленої роботи було визначити потенціал полімерів гребінчастої будови на основі полі(2-диметиламіно) етилметакрилату (ДМАЕМА) як носіїв для введення генів у протопласти моху Ceratodon purpureus (Hedw.) Brid. та оцінити рівень фрітотоксичності цих полімерів.

Матеріали та методи. Електрофорез ДНК проводили для вивчення комплексоутворення полі-ДМАEMA носіїв і плазмідної ДНК pSF3. Адаптований протокол ПЕГ-трансформації використано для трансформації протопластів моху C. purpureus за допомогою полі-DMAEMA носіїв. Для оцінювання токсичності полімерів щодо протопластів моху застосовано світлову мікроскопію. Загальну токсичність полімерів оцінювали за показником $\mathrm{IC}_{50}$.

Результати і обговорення. Формування комплексу ДНК плазміди pSF3 з носіями полі-ДМАЕМА виявлено за дії полімерів BGA-21, BGA-22(2ph), BG-24, BG-25, BG-26 у дозі 0,03 \%, а полімера BGA-22 - у дозі 0,1\%. Полі-ДМАЕМА носії здатні доставити плазмідну ДНК pSF3 у протопласти моху C. purpureus. Три стабільних

ISSN 1996-4536 (print) • ISSN 2311-0783 (on-line) • Біологічні Студії / Studia Biologica • 2021 • Том 15 / № 3 • С. 29-40 
трансформанти моху C. purpureus отримано з використанням полімера BGA-22, два клони - за використання носія BGA-21 і один клон - за використання полімерів BGA-22(2ph), BG-24, ВG-25, ВG-26. Полі-ДМАЕМА носії за робочої концентрації $(0,0025 \%)$ проявили низьку токсичність для протопластів моху C. purpureus. Виявлено 83,1-88,4 \% життєздатних протопластів моху C. purpureus за впливу досліджених носіїв. Показник виживання протопластів сягав 66,7-72,9 \% за дії полімерів у концентрації 0,025\%, яка в 10 разів перевищувала робочу концентрацію, використану для трансформації протопластів моху. $\mathrm{IC}_{50}$ полі-ДМАЕМА носіїв сягав 0,113-0,164 \% за концентрації, яка у 10 разів перевищувала $\mathrm{IC}_{50}$ традиційного носія - ПЕГ-6000.

Висновок. Нові синтетичні полі-DMAEMA носії здатні доставляти ген інтересу у протопласти моху C. purpureus і водночас мають фітотоксичність. Отже, поліДМАЕМА носії є перспективними для доставки генів у клітини рослин.

Ключові слова: полі(2-диметиламіно)етилметакрилат, полімерний носій, трансформація протопластів, мох Ceratodon purpureus, фрітотоксичність 